\title{
The novel gene $N y-1$ on potato chromosome IX confers hypersensitive resistance to Potato virus $Y$ and is an alternative to $R y$ genes in potato breeding for PVY resistance
}

\author{
K. Szajko $\cdot$ M. Chrzanowska $\cdot$ K. Witek \\ D. Strzelczyk-Żyta $\cdot$ H. Zagórska $\cdot$ C. Gebhardt $\cdot$ \\ J. Hennig • W. Marczewski
}

Received: 18 May 2007 / Accepted: 20 October 2007 / Published online: 6 November 2007

(C) Springer-Verlag 2007

\begin{abstract}
Hypersensitive resistance (HR) is an efficient defense strategy in plants that restricts pathogen growth and can be activated during host as well as non-host interactions. HR involves programmed cell death and manifests itself in tissue collapse at the site of pathogen attack. A novel hypersensitivity gene, $N y-1$, for resistance to Potato virus $Y$ (PVY) was revealed in potato cultivar Rywal. This is the first gene that confers HR in potato plants both to common and necrotic strains of PVY. The locus $N y-1$ mapped on the short arm of potato chromosome IX, where various resistance genes are clustered in Solanaceous genomes. Expression of HR was temperature-dependent in cv. Rywal. Strains $\mathrm{PVY}^{\mathrm{O}}$ and $\mathrm{PVY}^{\mathrm{N}}$, including subgroups $\mathrm{PVY}^{\mathrm{N}} \mathrm{W}$ and PVY ${ }^{\mathrm{NTN}}$, were effectively localized when plants were grown at $20^{\circ} \mathrm{C}$. At $28^{\circ} \mathrm{C}$, plants were systemically infected but no symptoms were observed. In field trials, PVY was restricted to the inoculated leaves and PVY-free tubers were produced. Therefore, the gene $N y-1$ can be useful for potato breeding as an alternative donor of
\end{abstract}

Communicated by R. Waugh.

K. Szajko · M. Chrzanowska · D. Strzelczyk-Żyta · H. Zagórska · W. Marczewski $(\square)$

Plant Breeding and Acclimatization Institute, Platanowa 19, 05831 Młochów, Poland

e-mail: w.marczewski@ihar.edu.pl

K. Witek · J. Hennig

Institute of Biochemistry and Biophysics, Polish Academy

of Sciences, Pawińskiego 5A, 02106 Warsaw, Poland

C. Gebhardt

Max-Planck Institute for Plant Breeding Research,

Carl von Linné Weg 10, 50829 Cologne, Germany
PVY resistance, because it is efficacious in practice-like resistance conferred by $R y$ genes.

\section{Introduction}

Plants have evolved complex genetic systems to defend against pathogen attack. Elucidation of the molecular mechanism of plant disease resistance is important for several reasons. First, understanding how plants respond to pathogens is critical for the application of engineering for increased crop resistance to viruses, viroids, bacteria and fungi. In addition, the determination of the pathway from initial recognition of a pathogen to the induction defencestrategy will yield insight into basic aspects of specific signal transduction pathways.

Potato virus $Y(\mathrm{PVY})$ is a member of the genus Potyvirus (Potyviridae family). Two main groups of PVY strains, $\mathrm{PVY}^{0}$ and $\mathrm{PVY}^{\mathrm{N}}$, separated according to their pathogenic properties, are the most harmful viruses in cultivated potato (Solanum tuberosum ssp. tuberosum). $\mathrm{PVY}^{0}$ (common, ordinary strain) induces leaf mottling, extensive necrotic and drop streak symptoms, and often leads to plant death. $\mathrm{PVY}^{\mathrm{N}}$ (tobacco veinal necrosis strain) causes, in general, mild mosaic symptoms in potato leaves (De Bokx and Huttinga 1981; Brunt 2001; Valkonen 2007).

A subgroup of $\mathrm{PVY}^{\mathrm{N}}$, designated as $\mathrm{PVY}^{\mathrm{NTN}}$, is responsible for potato tuber necrotic ringspot disease, which results in losses of tuber quality (Beczner et al. 1984). The second subgroup, $\mathrm{PVY}^{\mathrm{N}} \mathrm{W}$, originally described in Polish cv. Wilga, as PVY ${ }^{\mathrm{N}}$ Wi (Chrzanowska 1991), induces vein necrosis in Nicotiana tabaccum cv. Samsun and mild mosaic in potato plants, but is serologically related to $\mathrm{PVY}^{0}$ (Chrzanowska 1994), probably as the outcome of recombi- 
nation events in the virus coat protein gene (Glais et al. 2005).

In potato, there are two main types of resistance to PVY, extreme resistance (ER) and hypersensitive resistance (HR). The Ry genes for ER confer extremely high level of protection against different strains of PVY (Ross 1986; Valkonen et al. 1996). Three $R y$ genes have been localized by molecular mapping on potato chromosomes. $R y_{\text {sto }}$ (designated also as $R y-f_{\text {sto }}$ ) derived from S. stoloniferum and $R y_{a d g}$ from $S$. tuberosum ssp. andigena mapped on potato chromosomes XII (Flis et al. 2005; Song et al. 2005) and XI (Hämäläinen et al. 1997), respectively. The gene $R y_{c h c}$ derived from $S$. chacoense mapped to the distal end of potato chromosome IX (Sato et al. 2006). The gene $R y_{\text {sto }}$ was also localized on chromosome XI (Brigneti et al. 1997), in the same region, where $R y_{a d g}$ was mapped (Gebhardt and Valkonen 2001). Recently, however, the $R y_{a d g}-$ linked markers used in the $S$. stoloniferum mapping experiments did not confirm the position of $R y_{\text {sto }}$ on potato chromosome XI (Valkonen et al. 2007).

The HR to PVY is strain specific in potato. Hypersensitivity to $\mathrm{PVY}^{0}$ and/or $\mathrm{PVY}^{\mathrm{N}}$ was described in wild Solanum species (Valkonen 1997; Ruiz de Galarreta et al. 1998; Solomon-Blackburn and Barker 2001). HR was also observed in cultivated potato, however, only after infection with the ordinary strain of PVY (Jones 1990; Valkonen et al. 1998; Sorri et al. 1999). Potato cultivars expressing HR to PVY ${ }^{\mathrm{N}}$ infection were not reported so far (Valkonen 2007). The first HR gene, $N y_{t b r}$, causing necrotic response to $\mathrm{PVY}^{0}$ infection in potato mapped on potato chromosome IV (Celebi-Toprak et al. 2002). In this paper, we report the first potato HR gene, which induces necrotic response and restriction of common and necrotic variants of PVY. The gene, designated as $\mathrm{Ny}-1$, mapped on potato chromosome IX.

\section{Materials and methods}

\section{Plant material and PVY strains}

The tetraploid potato (Solanum tuberosum ssp. tuberosum, $2 n=4 x=48$ ) population 'RxA', consisting of $200 \mathrm{~F}_{1}$ individuals, was obtained from a cross between Rywal, a cultivar with HR to PVY and the susceptible cv. Accent. Rywal originated from a cross of Polish cv. Dalia and Polish clone DM 1696. This clone was developed from Dutch cv. Edzina $\times$ Polish clone DM 51/5-7 cross. Further pedigree information for cultivars Dalia and Edzina, and clone DM 51/5-7 are compiled in Świeżyński et al. (1997) and the potato pedigree database (http://www.dpw.wau.nl/pv). Four PVY variants: $\mathrm{PVY}^{0} \mathrm{LW}, \mathrm{PVY}^{\mathrm{N}} \mathrm{Ny}, \mathrm{PVY}^{\mathrm{N}} \mathrm{W}$ and
PVY ${ }^{\mathrm{NTN}} \mathrm{Bo}$, which derived from the corresponding potato cvs: Lipiński Wczesny, Nysa, Wilga and Bona, were multiplied and maintained in cv. Samsun tobacco plants.

\section{Resistance assays for PVY strains}

Two types of assays were performed to evaluate the resistance of cvs Rywal and Accent to PVY strains. Plants were grown for 2 weeks in the greenhouse and transferred 1 week before the infection experiments to growth chambers with controlled environmental conditions $\left(20\right.$ or $28^{\circ} \mathrm{C}$, $16 \mathrm{~h}$ light, $100 \mu \mathrm{m} / \mathrm{s} / \mathrm{m}^{2}, 8 \mathrm{~h}$ dark). For each cultivar, six detached leaves or six plants were mechanically inoculated with a sap extracted from the tobacco plants, infected with $\mathrm{PVY}^{0} \mathrm{LW}, \mathrm{PVY}^{\mathrm{N}} \mathrm{Ny}, \mathrm{PVY}^{\mathrm{N}} \mathrm{W}$ or $\mathrm{PVY}^{\mathrm{NTN}} \mathrm{Bo}$. Inoculated detached leaves and plants were divided into two groups. One group was incubated at $20^{\circ} \mathrm{C}$, the other at $28^{\circ} \mathrm{C}$. Watertreated detached leaves and plants were used as controls. Inoculated detached leaves were placed on a wet filter paper in two plastic trays, which were covered with glass plates to maintain high humidity. Hypersensitivity was visualized after 4-6 days. Nine days post-inoculation, $1 \mathrm{~g}$ samples of inoculated and non-inoculated upper leaves from each of the plants were collected in order to detect the virus by RT-PCR.

For the mapping experiments, two tuber-derived plants per clone of each $\mathrm{F}_{1}$ individuals of the 'RxA' population were screened for $\mathrm{HR}$ to $\mathrm{PVY}^{\mathrm{N}} \mathrm{W}$ and $\mathrm{PVY}^{\mathrm{NTN}} \mathrm{Bo}$ infection at $20^{\circ} \mathrm{C}$. In addition, three corresponding detached leaves were scored by inoculation with PVY ${ }^{\mathrm{NTN}}$ Bo. Plants which developed necrotic symptoms were classified as resistant.

\section{Detection of PVY RNA by RT-PCR}

RNA was isolated using TRIZOL method (Chomczyński and Sacchi 1987). Reverse-transcription reactions contained $1 \mu \mathrm{g}$ of DNase I treated RNA from PVY or mock inoculated plants. The reactions were primed with oligo(dT) and elongated by the PVY specific sequence (5'oligo(dTx30)GTCTCCTGATTGAAGTTTACAG3'). 200 U M-MuLV Reverse Transcriptase (Fermentas, Vilnius, Lithuania) were used to synthesize first-strand cDNA. PCR amplification from PVY coat protein RNA (PVYCP) was performed with the PVYCPf and PVYCPr primers for 30 cycles at $94^{\circ} \mathrm{C}$ for $30 \mathrm{~s}, 53^{\circ} \mathrm{C}$ for $30 \mathrm{~s}$, and $72^{\circ} \mathrm{C}$ for $45 \mathrm{~s}$. The primer sequences were: PVYCPf, 5'AAATACTCGG GCAACTCAATCACA3'; PVYCPr, 5'CACCGTCCAA CCCGAAAAG3'. They were based on coat protein sequences for various PVY strains, available in GenBank database. PrimerSelect software from Lasergene 6.1 set (DNASTAR Inc., Madison WI, USA) was used for primer design. 
Plant DNA isolation, PCR, electrophoresis, DNA cloning and sequencing

Extraction of plant genomic DNA and electrophoresis were performed as previously described (Flis et al. 2005). Intersimple sequence repeat (ISSR) markers were amplified in $20 \mu \mathrm{l}$ of $20 \mathrm{mM}$ Tris- $\mathrm{HCl} \mathrm{pH}$ 8.4, $50 \mathrm{mM} \mathrm{KCl}, 2 \%$ DMSO, $2.5 \mathrm{mM} \mathrm{MgCl} 2,0.2 \mathrm{mM}$ of each deoxynucleotide, $0.3 \mu \mathrm{M}$ of primer, containing $1 \mathrm{U} \mathrm{Taq}$ DNA Polymerase (Invitrogen, Carlsbad, CA, USA) and 30 ng genomic DNA as template. The PCR parameters were: 40 cycles of $94^{\circ} \mathrm{C}$ for $20 \mathrm{~s}, 42^{\circ} \mathrm{C}$ for $30 \mathrm{~s}, 72^{\circ} \mathrm{C}$ for $2 \mathrm{~min}$ and a final extension time of $10 \mathrm{~min}$ at $72^{\circ} \mathrm{C}$. The ISSR marker UBC $895_{1200}$ was cloned and sequenced as previously described (Marczewski et al. 2006) and compared to the NCBI sequence database with the BLASTN program.

Three markers: sequence characterized amplified region (SCAR) SC895 ${ }_{1139}$ (NCBI GenBank accession EF555209), GP41 $_{443}$ (AJ487356) and conserved ortholog set II (COSII) C2_At3g16840 1100 (SGN-U284031) were amplified in $20 \mu$ lof $20 \mathrm{mM}$ Tris- $\mathrm{HCl} \mathrm{pH} 8.4,50 \mathrm{mM} \mathrm{KCl}, 1.5 \mathrm{mM}$ $\mathrm{MgCl}_{2}, 0.1 \mathrm{mM}$ of each deoxynucleotide, $0.2 \mu \mathrm{M}$ of each primer, containing $1 \mathrm{U} \mathrm{Taq}$ DNA Polymerase (Invitrogen) and $30 \mathrm{ng}$ genomic DNA as template. Forward and reverse primers, designed as described in Marczewski et al. (2006), were: f: 5'GGTAGCTCTTGATCTCGTCTT3', r: 5'GTA GCTCTTGATCACCCATTT3' for SC895; f: 5'GTTGGT ACCAGGCTTGTT3', r: 5'CATTCGGTGCTTTAGGAT3' for GP41 and f: 5'TCCAGTGTCCAAAGAAAGAAAA3', r: 5'ATGCTCATGTCCCCGAAACC3' for C2_At3g16840. The PCR parameters for amplifying $\mathrm{SC}^{-} 95_{1139}$ and C2_At3g $16840_{1100}$ were: $94^{\circ} \mathrm{C}$ for $60 \mathrm{~s}$ followed by 40 cycles of $93^{\circ} \mathrm{C}$ for $25 \mathrm{~s}, 56^{\circ} \mathrm{C}$ for $35 \mathrm{~s}, 72^{\circ} \mathrm{C}$ for $90 \mathrm{~s}$ and a final extension time of $5 \mathrm{~min}$ at $72^{\circ} \mathrm{C}$. GP $41_{443}$ was amplified at the annealing temperature of $54^{\circ} \mathrm{C}$.

\section{Detection of PVY in field-grown plants}

Four groups of cv. Rywal plants, 60 plants each, were subjected to PVY-exposure field trials at Młochów, during five vegetation seasons, 1999-2003. One group consisted of plants grown from the virus-free tubers, whereas in the other groups three successive tuber progenies were planted. Each third row of the field trials was planted with tubers of PVY-infected potato plants. In addition, during each year 120 plants grown from field tubers harvested in the northeastern region of Poland were planted in a greenhouse at Młochów. The presence of PVY was tested in leaves of 5to 6-week-old plants by enzyme-linked immunosorbent assay (ELISA) using the monoclonal cocktail Bioreba AG kit (Reinach, Switzerland).
Mapping of the locus $N y-1$

The diploid mapping population 'Erwinia' (Zimnoch-Guzowska et al. 2000) was used to map the SCAR marker SC895 1139 linked to the gene $N y-1$. SC895 1139 , amplified from parental clone DG 81-68, was scored as presence or absence of the marker fragment in $78 \mathrm{~F}_{1}$ progeny. The map position was identified relative to the amplified fragment length polymorphism (AFLP) and restriction fragment length polymorphism (RFLP) map existing for this population using the software package MAPRF (E. Ritter, NEIKER, 01080 Victoria, Spain). The position of $\mathrm{Ny}-1$ in cv. Rywal was confirmed in the population 'RxA' by detecting linkage to the anchor markers GP41 and C2_At3g16840, specific for potato chromosome IX (PoMaMo database, http://gabi.rzpd.de/database/maps.shtml) and tomato chromosome 9 (Tomato-EXPEN 2000 map, http:// www.sgn.cornell.edu/search/markers/markersearch.pl), respectively.

\section{Results}

Reaction of cvs Rywal and Accent to infection with PVY strains

When detached leaves or whole plants of PVY susceptible cv. Accent were mechanically inoculated with strains PVY${ }^{\mathrm{O}} \mathrm{LW}, \mathrm{PVY}^{\mathrm{N}} \mathrm{Ny}, \mathrm{PVY}^{\mathrm{N}} \mathrm{W}$ and PVY ${ }^{\mathrm{NTN}}$ Bo, no symptoms were observed at 20 or $28^{\circ} \mathrm{C}$ (not shown). The systemic, symptomless infection was also associated with plants of $\mathrm{cv}$. Rywal inoculated and grown at $28^{\circ} \mathrm{C}$. In contrast, at $20^{\circ} \mathrm{C}$, necrotic lesions were observed in leaves of cv. Rywal, 4-6 days post-inoculation for each strain (Fig. 1). The viral RNA was not detected in the upper, non-inoculated leaves of $\mathrm{cv}$. Rywal collected 9 days after inoculation (Table 1). Increasing the temperature from 20 to $28^{\circ} \mathrm{C}$ allowed the virus to occasionally move from inoculated leaves to leaves on upper parts of the plant, which remained symptom-free but contained detectable amounts of PVY. The systemic virus spread did not occur when the inoculated leaves were detached from the plant prior to their transfer to the higher temperature (not shown). However, during 5 years of experiments for the field-grown plants, no more than occasional systemic infections with PVY, resulting in plant death, were observed.

Mapping of the gene $N y-1$

Hypersensitive resistance was observed in $93 \mathrm{~F}_{1}$ hybrids of the mapping population ' $\mathrm{RxA}^{\prime}$ ' using both the detached leaf 


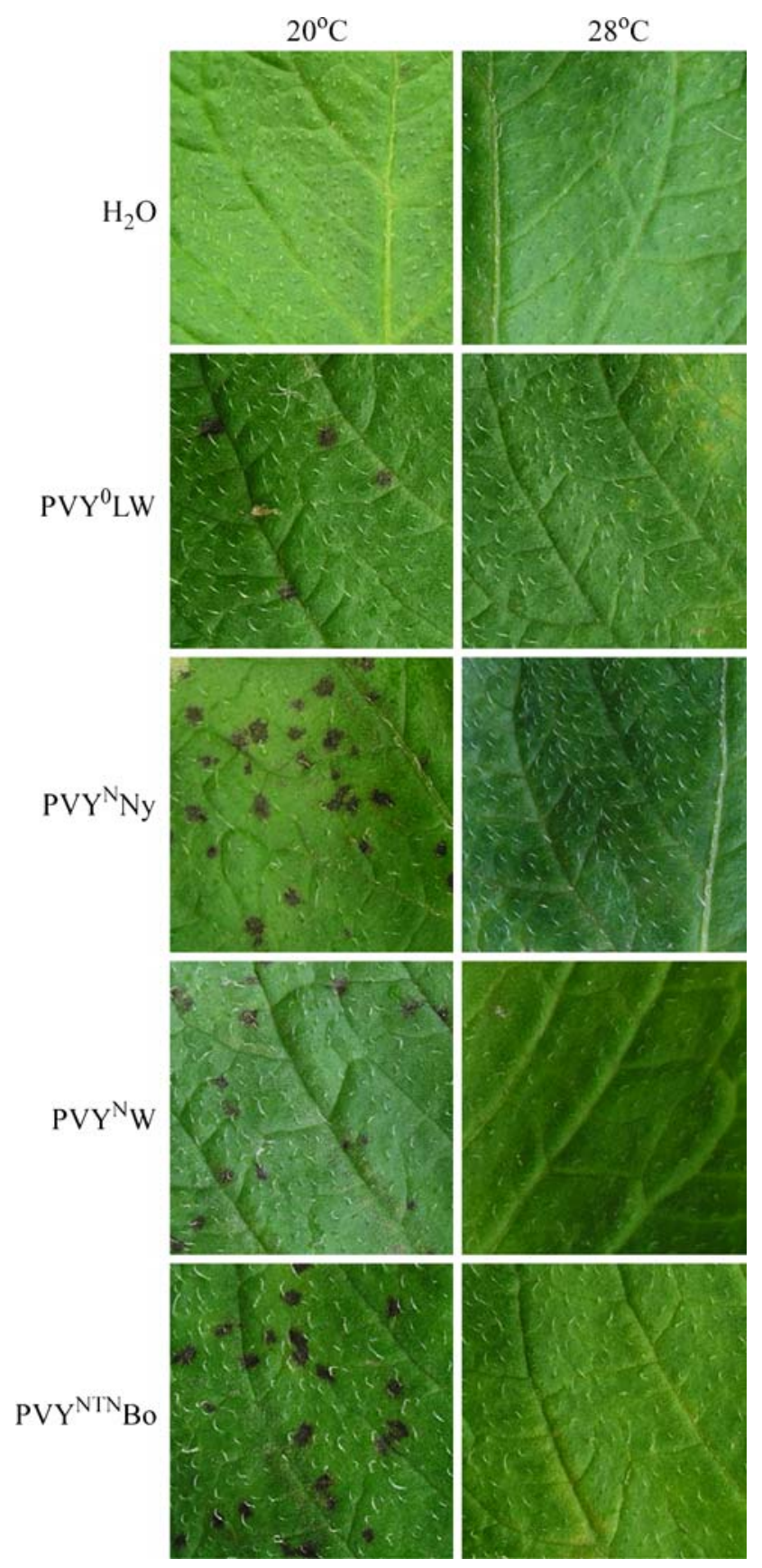

Fig. 1 Response of cv. Rywal plants to infection with $\mathrm{PVY}^{0} \mathrm{LW}$, $\mathrm{PVY}^{\mathrm{N}} \mathrm{Ny}, \mathrm{PVY}^{\mathrm{N}} \mathrm{W}$ or PVY ${ }^{\mathrm{NTN}}$ Bo. The pictures of detached leaves incubated at 20 or $28^{\circ} \mathrm{C}$ were taken 6 days post-inoculation. Experiments were repeated twice with similar results

and the whole plant-inoculation tests. The PVY susceptible group consisted of $107 \mathrm{~F}_{1}$ hybrids. The segregation ratio of $1: 1\left(\chi^{2}=0.98, P=0.32\right)$ fits the genetic model of a single, dominant gene for HR to PVY in simplex state in $\mathrm{cv}$. Rywal.

Seventy-eight ISSR primers, that were informative in previous studies (Flis et al. 2005), were tested by PCR in the parental DNA samples. Of 16 PCR products generated
Table 1 Presence of PVY RNA and symptoms in leaves of plants from cv. Rywal inoculated with $\mathrm{PVY}^{0} \mathrm{LW}, \mathrm{PVY}^{\mathrm{N}} \mathrm{Ny}, \mathrm{PVY}^{\mathrm{N}} \mathrm{W}$ or $\mathrm{PVY}^{\mathrm{NTN}} \mathrm{Bo}$

\begin{tabular}{llllll}
\hline Leaves & $20^{\circ} \mathrm{C}$ & & & $28^{\circ} \mathrm{C}$ \\
\cline { 2 - 3 } \cline { 5 - 6 } \cline { 5 - 6 } & RT-PCR & Symptoms & & RT-PCR & Symptoms \\
\hline Water-treated $^{2}$ & - & NS & & - & NS \\
PVY-inoculated $^{\mathrm{a}}$ & + & $\mathrm{HR}$ & + & $\mathrm{NS}$ \\
Non-inoculated $^{\mathrm{b}}$ & - & $\mathrm{NS}$ & + & $\mathrm{NS}$ \\
\hline
\end{tabular}

Experiments were repeated twice with similar results

$N S$ no symptoms; $H R$ hypersensitive response; -, absence of amplicon; + , presence of PVY-specific product

a Leaves collected 6 days post-inoculation

b Upper leaves collected 9 days post-inoculation

specifically in the resistant parent $\mathrm{cv}$. Rywal, only one, a $1,200 \mathrm{bp}$ long DNA fragment amplified using primer UBC895 (5'AGAGTTGGTAGCTCTTGATC3') was seen as a faint band (Fig. 2, lane 1) in a bulked DNA sample constructed from eight HR progeny. The marker was not observed in the susceptible DNA bulk. UBC $895_{1200}$ was cloned and sequenced in order to obtain more reliable and specific PCR amplification. Based on the cloned 1,152 bp marker, which revealed no apparent homology to any sequences available in GenBank, the SCAR marker SC895 ${ }_{1139}$ (EF555209) was developed as the clear, strong PCR product, amplified in cv. Rywal (Fig. 2, lane 3). SC895 1139 was used to screen the $200 \mathrm{~F}_{1}$ individuals of the 'RxA' family. The marker fragment was observed in all 93 resistant and in 1 susceptible $F_{1}$ plant, indicating a close linkage $(0.5 \mathrm{cM})$ between the SCAR marker and the locus $N y-1$. Segregation of $\mathrm{SC} 895_{1139}$ in the 'Erwinia' mapping population (Zimnoch-Guzowska et al. 2000) revealed the map position of $N y-1$ on the short arm of potato chromosome IX. The chromosome location was confirmed when a $443 \mathrm{bp}$ sequence tagged site (STS) amplicon (Fig. 2, lane 5) of the chromosome IX specific marker GP41 (http:// gabi.rzpd.de/database/maps.shtml) was positioned $1 \mathrm{cM}$ from $N y-1$ in cv. Rywal. The locus $N y-1$ was also found to be separated by $6 \mathrm{cM}$ from the COSII marker C2_At3g16840 described in the reference Tomato Genetic Map at position $88 \mathrm{cM}$ on tomato chromosome 9 (Wu et al. 2006). C2_At3g16840 was scored based on two restriction fragments of 350 and $500 \mathrm{bp}$, generated after TaqI digestion of the approximately $1,100 \mathrm{bp}$ amplicon (Fig. 2, lane 7). The marker GP41 was found in the Tomato-EXPEN 1992 genetic map at position $104.8 \mathrm{cM}$ on chromosome 9 (http://www.sgn.cornell.edu/cview). The syntenic relationships between tomato and potato genomes implicate, therefore, the proximal orientation of C2_At3g16840 and the distal locations of SC895 1139 and GP41 in the linkage group IX (Fig. 3). 

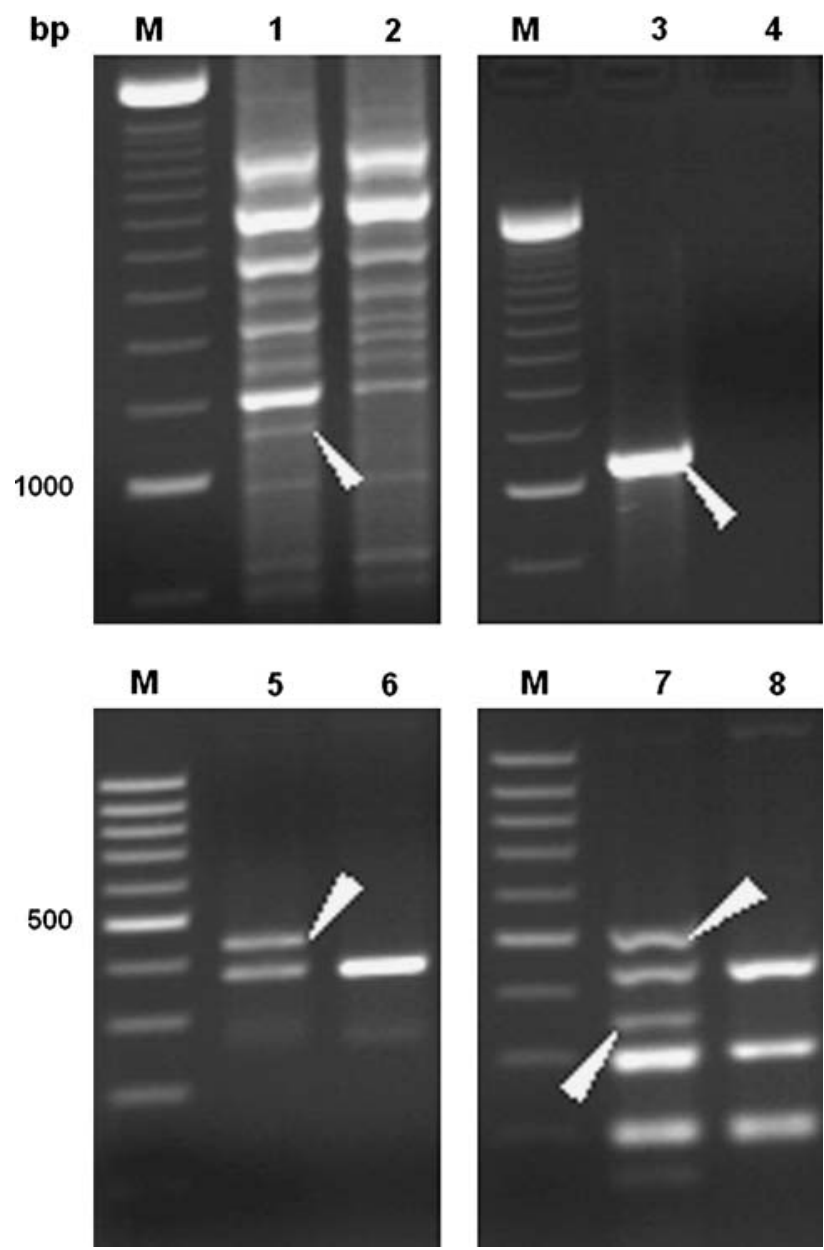

Fig. 2 Patterns of amplified DNA of resistant parent cv. Rywal (lanes 1, 3, 5 and 7) and susceptible parent Accent (lanes 2, 4, 6 and 8), indicating the ISSR marker UBC895 1200 (lane 1), the STS marker SC895 1139 (lane 3), the SCAR marker GP41 443 (lane 5) and the COSII marker C2_At3g16840 after digestion with TaqI (lanes 7 and 8). Arrows point to the marker products that were scored. Lanes $M$ contain the 250-bp (upper) and 100-bp (lower) DNA ladders as molecular size markers

\section{Discussion}

Plant resistance is often accompanied by rapid tissue necrotization at pathogen entry sites, referred to as HR. High temperature may induce a switch from necrotic reactions to absence or mild systemic symptoms in virus infected plants (Malamy et al. 1992; Zheng et al. 2005). For example, HR to $\mathrm{PVY}^{\mathrm{N}}$ in $S$. sparsipilum and S. sucrense and to $\mathrm{PVY}^{0}$ in potato $\mathrm{cv}$. Pito was efficiently expressed at temperatures $16-18^{\circ} \mathrm{C}$, indicated by the local and/or systemic necrosis, while at higher temperatures $\left(19 / 24^{\circ} \mathrm{C}\right)$, only leaf drop and mosaic symptoms were developed (Valkonen 1997). The temperature-sensitive response was also observed in potato plants with the genes $N x$ and $N b$, which induced HR to

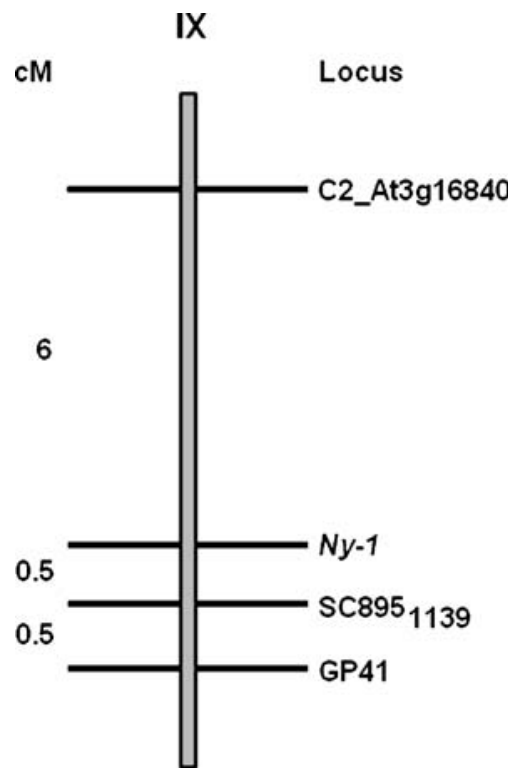

Fig. 3 Potato linkage group IX of PVY resistant parent cv. Rywal, including the position of the locus $N y-1$. The tetraploid population obtained from a cross between potato cultivars Rywal and Accent was used for the mapping

Potato virus X (PVX) infection (Adams et al. 1986). HR induced by $N y-1$ in cv. Rywal was efficiently developed at $20^{\circ} \mathrm{C}$, whereas local necrotic lesions were not revealed in plants grown constitutively at elevated $\left(28^{\circ} \mathrm{C}\right)$ temperature. Moreover, this temperature allowed the plants to be systemically infected with $\mathrm{PVY}^{0} \mathrm{LW}, \mathrm{PVY}^{\mathrm{N}} \mathrm{Ny}, \mathrm{PVY}^{\mathrm{N}} \mathrm{W}$ or $\mathrm{PVY}^{\mathrm{NTN}} \mathrm{Bo}$ with the absence of viral symptom expression. In Poland, potato cultivars are grown between April and August, when daily minimum and maximum temperatures may reach the values below $10^{\circ} \mathrm{C}$ and above $35^{\circ} \mathrm{C}$. However, throughout 5 years of the field experiments at Młochów plants of cv. Rywal produced PVY-free tubers. Młochów is located in the central region of Poland, where PVY infection pressure is intense (Gabriel 1995). PVY was also not revealed in tubers collected in the northeastern region of Poland. Moreover, during several years of cv. Rywal reproduction at the Plant Breeding Station Szyldak, northern Poland, harvested tubers were PVY-free (R. Bruski, personal communication). It is possible that the natural PVY infection pressure caused by aphids, which transmit PVY non-persistently, was too slow to break the virus restriction at the site of infection and activate its systemic movement in $N y-1$ possessing plants, even at the higher temperatures. To our knowledge cv. Rywal is the first commercial potato cultivar, in which HR to both common and necrotic PVY strains, including PVY ${ }^{\mathrm{N}} \mathrm{W}$ and $\mathrm{PVY}^{\mathrm{NTN}}$, was effectively expressed.

The extreme resistance gene $R y_{\text {chc }}$ mapped recently on potato chromosome IX in Japanese cv. Konafubuki was tightly linked to the marker TG421 (Sato et al. 2006). The 
Ny-1-linked marker C2_At3g16840 was found to be linked to TG421, within $5 \mathrm{cM}$, in the reference Tomato-EXPEN 2000 map (http://www.sgn.cornell.edu/search/markers/ markersearch.pl). Therefore, $R y_{c h c}$ and $N y-1$ may be new members of the resistance hot spot on potato chromosome IX, in which resistance genes and quantitative trait loci to various pathogens have been previously described (Marczewski et al. 2006; Rouppe van der Voort et al. 2000; Simko et al. 2004; Smilde et al. 2005; Śliwka et al. 2006; Tommiska et al. 1998; Zimnoch-Guzowska et al. 2000).

$R y$ genes for extreme resistance to PVY $R y_{\text {sto }}$ have been introgressed mainly into European potato cultivars (Flis et al. 2005; Song et al. 2005). However, ER cultivars and breeding lines often exhibit male sterility (Lössl et al. 2000), which limits their usefulness in potato breeding programs. Cultivars and breeding clones derived from Polish, German, Dutch and North American gene pools are in the pedigree of cv. Rywal. Hypothetically, some of them can possess the gene $N y-1$, and the $N y-1$-linked markers should be helpful for their selection. Therefore, we postulate that $N y-1$, which provides a level of the field resistance to PVY as satisfactory as the $R y$ genes, may be available and useful in several potato breeding programs.

Acknowledgments We thank Bogdan Flis and Ewa Zimnoch-Guzowska for helpful comments on the manuscript and Andrzej Pałucha for the oligo(dT)-PVY primer sequence. The research was supported by the State Committee for Scientific Research in Poland, project PBZ/ $\mathrm{KBN} / 110 / \mathrm{PO} 4 / 2004$.

\section{References}

Adams SE, Jones RAC, Coutts RHA (1986) Effect of temperature on potato virus $\mathrm{X}$ infection in potato cultivars carrying different combinations of hypersensitivity genes. Plant Pathol 35:517-526

Beczner L, Horvath J, Romhanyi I, Forster H (1984) Studies on the etiology of tuber necrotic ringspot disease in potato. Potato Res 27:339-352

Brigneti G, Garcia-Mas J, Baulcombe DC (1997) Molecular maping of the potato virus $\mathrm{Y}$ resistance gene $R y_{\text {sto }}$ in potato. Theor Appl Genet 94:198-203

Brunt AA (2001) Potyviruses. In: Loebenstein G, Berger PH, Brunt AA, Lawson RH (eds) Virus and virus-like diseases of potatoes and production of seed-potatoes. Kluwer, Dordrecht, Boston, London, pp 77-84

Celebi -Toprak F, Slack SA, Jahn MM (2002) A new gene, $N y_{t b r}$, for hypersensitivity to Potato virus $Y$ from Solanum tuberosum maps to chromosome IV. Theor Appl Genet 104:669-674

Chomczyński P, Sacchi N (1987) Single-step method of RNA isolation by acid guanidinium thiocyanate-phenol-chloroform extraction. Anal Biochem 162:156-159

Chrzanowska M (1991) New isolates of the necrotic strain of potato virus $\mathrm{Y}\left(\mathrm{PVN}^{\mathrm{N}}\right)$ found recently in Poland. Potato Res 34:179-182

Chrzanowska M (1994) Differentiation of potato virus Y (PVY) isolates. Phytopathol Pol 8:15-20

De Bokx JA, Huttinga H (1981) Potato virus Y. CMI/AAB Description of plant viruses no. 242
Flis B, Hennig J, Strzelczyk-Żyta D, Gebhardt C, Marczewski W (2005) The $R y-f_{\text {sto }}$ gene from Solanum stoloniferum for extreme resistant to Potato virus $Y$ maps to potato chromosome XII and is diagnosed by PCR marker GP122 $2_{718}$ in PVY resistant potato cultivars. Mol Breed 15:95-101

Gabriel W (1995) Une méthode d'utilisation possible de l'échelle de 1 á 9 pour l'évaluation de la résistance aux virus chez les cultivars de pomme de terre. Potato Res 38:297-305

Gebhardt C, Valkonen JPT (2001) Organization of genes controlling disease resistance in the potato genome. Annu Rev Phytopathol 39:79-102

Glais L, Tribodet M, Kerlan C (2005) Specific detection of the PVY ${ }^{\mathrm{N}}$ W variant of Potato virus $Y$. J Virol Methods 125:131-136

Hämäläinen JH., Watanabe KN, Valkonen JPT, Arihara A, Plaisted RL, Pehu E, Miller L, Slack SA (1997) Mapping and marker-assisted selection for a gene for extreme resistance to potato virus Y. Theor Appl Genet 94:192-197

Jones RAC (1990) Strain group specific and virus specific hypersensitive reactions to infection with potyviruses in potato cultivars. Ann Appl Biol 117:93-105

Lössl A, Götz M, Braun A, Wenzel G (2000) Molecular markers for cytoplasm in potato: male sterility and contribution of different plastid-mitochondrial configurations to starch production. Euphytica 116:221-230

Malamy J, Hennig J, Klessig DF (1992) Temperature-dependent induction of salicylic acid and its conjugates during the resistance response to tobacco mosaic virus infection. Plant Cell 4:359-366

Marczewski W, Strzelczyk-Żyta D, Hennig J, Witek K, Gebhardt C (2006) Potato chromosomes IX and XI carry genes for resistance to potato virus M. Theor Appl Genet 112:1232-1238

Rouppe van der Voort J, van der Vossen E, Bakker E, Overmars H, van Zandvoort P, Hutten R, Klein-Lankhorst R, Bakker J (2000) Two additive QTLs conferring broad-spectrum resistance in potato to Globodera pallida are localized on resistance gene clusters. Theor Appl Genet 101:1122-1130

Ross H (1986) Potato breeding-problems and perspectives. J Plant Breed Suppl 13

Ruiz de Galarreta JI, Carrasco A, Salazar A, Barrena I, Iturritxa E, Marqinez R, Legorburu F J, Ritter E (1998) Wild Solanum species as resistance sources against different pathogens of potato. Potato Res 41:57-68

Sato M, Nishikawa K, Komura K, Kosaka K (2006) Potato virus $Y$ resistance gene, $R y_{\text {chc }}$, mapped to the distal end of potato chromosome 9. Euphytica 149:367-372

Simko I, Constanzo S, Haynes KG, Christ BJ, Jones RW (2004) Linkage disequilibrium mapping of a Verticilium dahliae resistance quantitative trait locus in tetraploid potato (Solanum tuberosum) through a candidate gene approach. Theor Appl Genet 108:217224

Smilde WD, Brigneti G, Jagger L, Perkins S, Jones JDG (2005) Solanum mochiquense chromosome IX carries a novel late blight resistance gene Rpi-moc1. Theor Appl Genet 110:252258

Solomon-Blackburn RM, Barker H (2001) A review of host majorgene resistance to potato viruses $\mathrm{X}, \mathrm{Y}, \mathrm{A}$ and $\mathrm{V}$ in potato: genes, genomics and mapped locations. Heredity 86:8-16

Song YS, Hepting L, Schweizer G, Hartl L, Wenzel G, Schwarzfischer A (2005) Mapping of extreme resistance to PVY $\left(R y_{\text {sto }}\right)$ on chromosome XII using anther-culture-derived primary dihaploid potato lines. Theor Appl Genet 111:879-887

Sorri VA, Watanabe KN, Valkonen JPT (1999) Predicted kinase-3a motif of a resistance gene analogue as a unique marker for virus resistance. Theor Appl Genet 99:164-170

Śliwka J, Jakuczun H, Lebecka R, Marczewski W, Gebhardt, Zimnoch-Guzowska E (2006) A novel late blight resistance gene 
Rpi-phul mapped to potato chromosome IX is not related to long vegetation period. Theor Appl Genet 113:685-695

Świeżyński KM, Haynes KG, Hutten RCB, Sieczka MT, Watts P, Zimnoch-Guzowska E (1997) Pedigree of European and NorthAmerican potato varieties. Plant Breed Seed Sci 41(1 supplement):3-149

Tommiska TJ, Hämäläinen JH, Watanabe KN, Valkonen JPT (1998) Mapping of the gene Nxphu that controls hypersensitive resistance to potato virus X in Solanum phureja IvP35. Theor Appl Genet 96:840-843

Valkonen JPT (1997) Novel resistances to four potyviruses in tuberbearing potato species, and temperature-sensitive expression of hypersensitive resistance to potato virus Y. Ann Appl Biol 130:91-104

Valkonen JPT (2007) Viruses: economical losses and biotechnological potential. In: Vreugdenhil D, Bradshaw J, Gebhardt C, Govers F, Taylor M, MacKerron D, Ross H (eds) Potato biology and biotechnology: advances and perspectives, Elsevier, Amsterdam, pp 619-641

Valkonen JPT, Jones RAC, Slack SA, Watanabe KN (1996) Resistance specificity to viruses in potato: standardization of nomenclature. Plant Breed 115:433-438
Valkonen JPT, Rokka V-M, Watanabe KN (1998) Examination of the leaf-drop symptom of virus-infected potato using anther culturederived haploids. Phytopathology 88:1073-1077

Valkonen JPT, Wiegmann K, Hämäläinen JH, Marczewski W, Watanabe KN (2007) Evidence for utility of the same PCR-based markers for selection of extreme resistance to Potato virus $Y$ controlled by $R y_{\text {sto }}$ of Solanum stoloniferum derived from different sources. Ann Appl Biol (in press)

Wu F, Mueller LA, Crouzillat D, Pétiard V, Tanksley SD (2006) Combining bioinformatics and phylogenetics to identify large sets of single-copy orthologous genes (COSII) for comparative, evolutionary and systematic studies: a test case in the euasterid plant blade. Genetics 174:1407-1420

Zheng C, Chen P, Gergerich R (2005) Effect of temperature on the expression of necrosis in soybean infected with Soybean mosaic virus. Crop Sci 45:916-922

Zimnoch-Guzowska E, Marczewski W, Lebecka R, Flis B, SchaferPregl R, Salamini F, Gebhardt C (2000) QTL analysis of new sources of resistance to Erwinia carotovora ssp. atroseptica in potato done by AFLP, RFLP, and resistance-gene-like markers. Crop Sci 40:1156-1167 